\title{
Underweight Indian Women at a Risk for Developing Breast Cancer: A Retrospective Study
}

\author{
Mrunal Ketkar', Amrita Ulhe², Minal Mahajan², Karamchand Patil², Ruchika \\ Kaul-Ghanekar ${ }^{2}$
}

${ }^{1}$ Department of Surgery and Oncology, Bharati Vidyapeeth Hospital and Research Centre (BVHRC), India. ${ }^{2}$ Cancer Research Lab, Interactive Research School for Health Affairs (IRSHA), Bharati Vidyapeeth (Deemed to be) University, Maharashtra, India. ${ }^{3}$ Department of Community Medicine, Bharati Vidyapeeth (Deemed to be) University Medical College, Maharashtra, India.

\begin{abstract}
Background: Breast cancer is the leading cancer diagnosed in Indian women. Lifestyle related factors such as high body mass index (BMI) and obesity have been recognized as major risk factors for the development of breast cancer. However, India has higher proportion of underweight population and recently positive correlation has been reported between underweight and increased risk of breast cancer. We have attempted to study an association between low BMI and total body fat percentage with breast cancer risk by performing retrospective analysis on a small sample size of 41 female patients diagnosed with breast cancer. The data was collected from Department of Oncology, Bharati Vidyapeeth Hospital and Research Centre (BVHRC), Pune, India. Methods: Binary logistic regression was performed to estimate odds ratios (ORs) and to examine the predictive effect of each factor on the breast cancer risk. Results: It was observed that underweight population displayed higher risk of breast cancer development based on BMI (OR-15.40) and body fat \% (OR-1.33). Conclusion: This pilot study suggests that low body mass index may be related to poor prognosis in breast cancer and thus warrants further studies on a larger sample size to establish a positive correlation.
\end{abstract}

Keywords: Breast cancer- body mass index- body fat percentage

Asian Pac J Cancer Care, 6 (3), 305-309

\section{Introduction}

India has the highest number of underweight adults in the world [1]. Epidemiological studies conducted in different geographical areas of India have suggested an association between low body mass index and increased risk of mortality and health-related quality of life [2]. In India, breast cancer is the leading cancer diagnosed in women. According to Indian Council of Medical Research (ICMR) report, based on cancer registries from different parts of India, number of breast cancer cases were predicted to rise by $85 \%$ in 2020 [3]. Lifestyle related risk factors such as high body mass index (BMI) and obesity have been recognized as independent risk factors for the development of breast cancer by many researchers $[4,5]$. Various studies have demonstrated a positive correlation
Submission Date: 12/28/2020Ａcceptance Date: 07/20/2021

\footnotetext{
Corresponding Authors:

Dr. Mrunal Ketkar and Dr. Ruchika Kaul-Ghanekar

Department of Surgery and Oncology, Bharati Vidyapeeth Hospital and Research Centre (BVHRC), Pune- 411043, Maharashtra, India. Cancer Research Lab., Interactive Research School for Health Affairs (IRSHA), Bharati Vidyapeeth Deemed to be University, Pune-Satara Road, Pune-411043, Maharashtra, India.

Emails: mrunalnitin@gmail.com, ruchika.kaulghanekar@gmail.com

Amrita Ulhe and Minal Mahajan have equal contribution in this study.
}

between obesity and incidence of breast cancer that would affect the survival of postmenopausal women with breast cancer [6-8].

However, several studies have suggested that breast cancer patients who are underweight could be at a higher risk than normal weight for recurrence and mortality [4, 9-11]. Recently, low BMI in young breast cancer patients with lymph node metastases, was reported to be of prognostic significance [12]. It has been hypothesized that a low BMI may result in lack of breast fat resulting into lower levels of ovarian hormones in the early adult life, which may lead to increased risk of breast cancer [13]. Thus, the present study has attempted to establish a correlation between lower BMI and total body fat with 
breast cancer risk.

\section{Materials and Methods}

\section{Study population}

The present retrospective study included 41 females diagnosed with breast cancer (cases) and 24 healthy females (control), who visited Department of Surgery and Oncology, Bharati Vidyapeeth Hospital and Research Centre (BVHRC), Pune, India during the period of 20142016 (Ethics approval no.- BVDU/MC/02).

\section{Data collection}

Information on anthropometric factors of cases such as age, weight, height and body fat percentage was collected from the hospital records of Department of Surgery and Oncology, BVHRC. BMI was calculated as weight in kilograms divided by height in meters square $\left(\mathrm{kg} / \mathrm{m}^{2}\right)$. Controls were selected among females who visited awareness camp organized by BVHRC. Females aged below 30 and above 80, diagnosed with gynecological malignancies were excluded from the control study population.

\section{Statistical analysis}

Descriptive statistics was used to describe the data. For quantitative variables, mean with standard deviation and for qualitative variables, frequency with percentage was used to describe the data. Chi-Square test and independent sample $t$ test were performed to assess the significance of age, weight, height, BMI and total body fat percentage between breast cancer patients and controls. Binary logistic regression was performed to estimate odds ratios (ORs) and to examine the predictive effect of each factor on the risk for breast cancer. All the statistical assessments were two-sided and considered to be significant with $\mathrm{p}$-value $<0.05$. All the statistical analysis were performed by using STATA15 software.

\section{Results}

\section{Characteristics of the study population}

In this study, mean age of breast cancer cases and controls was $54.12 \pm 13.42$ and $49.54 \pm 11.98$ years, respectively (Table 1). Mean height of cases and controls was $156.8 \pm 4.74 \mathrm{~cm}$ and $150.3 \pm 6.25 \mathrm{~cm}$, respectively. The study cases weighed between $42-79 \mathrm{~kg}$ while the controls weighed between $33.5-77 \mathrm{~kg}$, thereby showing that the mean weights were similar for both the groups
(51.76 kg and $52.47 \mathrm{~kg}$, respectively) $(\mathrm{p}=0.2307)$. Mean BMI of breast cancer cases and controls was $21.03 \pm 4.00$ and $23.17 \pm 4.01$, respectively whereas mean body fat $\%$ was $25.85 \pm 5.24$ and $27.93 \pm 8.67$, respectively.

\section{BMI as a risk factor for breast cancer}

Among the breast cancer cases, 53.65\% showed low BMI (<18.5), 24.39\% showed normal BMI (18.5-24.9\%) and $21.95 \%$ showed high BMI $(25-29.9 / \geq 30)$ and the cases were categorized into underweight, normal and overweight/ obese groups, respectively (Table 2). Odds ratio above 1 demonstrated the predictive effect of high risk for each factor. Based on BMI, underweight population displayed nearly 15 -fold higher risk $(\mathrm{OR}=15.40$ and $\mathrm{p}<0.0005)$ of developing breast cancer compared to overweight cases $(\mathrm{OR}=1.57$ and $\mathrm{p}<0.477)$. Thus, BMI classification showed a significant association with breast cancer occurrence.

\section{Body fat percentage as a risk factor for breast cancer}

The number of underweight breast cancer cases showing low body fat percentage were $60.97 \%$, which was higher than the number of healthy underweight controls $(33.33 \%)$ with an OR of $1.33(\mathrm{p}<0.0636)$ (Table 3). However, number of overweight breast cancer cases constituted $21.95 \%$ compared to $54.17 \%$ of healthy overweight controls with an odds ratio of $0.30(\mathrm{p}<0.136)$. Thus, based on body fat percentage too, underweight population displayed a higher risk of developing breast cancer.

\section{Discussion}

In this study, we have attempted to find an association between BMI and body fat levels as risk factor for breast cancer. The study was conducted on a pilot scale and the cases have not been stratified with respect to hormone receptor or menopausal status. We found that underweight $(\mathrm{BMI}<18.5)$ breast cancer cases displayed nearly 15 -fold higher risk for the disease. Based on body fat percentage, the proportion of underweight females was higher among breast cancer patients than among healthy controls.

The complex relationship between obesity and breast cancer has been studied at various levels such as BMI, different measures of obesity, hormonal or menopausal status in patients, ethnicity, stage of cancer and so on. Overweight women have been reported to have increased risk for developing breast cancer $(\mathrm{OR}=2.29)$ compared to women with normal BMI in both pre- and post-

Table 1. Characteristics of Study Population

\begin{tabular}{lccc}
\hline Variables & Breast cancer cases $(\mathrm{n}=41)$ & Controls $(\mathrm{n}=24)$ & P value \\
\hline Age (years) & $54.12 \pm 13.42$ & $49.54 \pm 11.98$ & 0.1724 \\
Height (cms) & $156.8 \pm 4.74$ & $150.3 \pm 6.25$ & $<0.001^{*}$ \\
Weight (Kgs) & $51.76 \pm 10.42$ & $52.47 \pm 10.28$ & 0.7894 \\
Body mass index (BMI) & $21.03 \pm 4.00$ & $23.17 \pm 4.01$ & $0.0420 *$ \\
Body fat \% & $25.85 \pm 5.24$ & $27.93 \pm 8.67$ & 0.2307 \\
\hline
\end{tabular}

Data has been represented as Mean $\pm \mathrm{SD} ; * \mathrm{p}<0.05, * * \mathrm{p}<0.01, * * * \mathrm{p}<0.001$ 
Table 2. Association between BMI and Risk of Breast Cancer

\begin{tabular}{|c|c|c|c|c|}
\hline Variable (BMI) & No. of Breast cancer cases (\%) & No. of Controls (\%) & OR (95\%confidence interval) & $P$ value \\
\hline $\begin{array}{l}\text { Underweight } \\
\qquad(<18.5)\end{array}$ & $22(53.65)$ & $02(8.33)$ & $15.40(2.92$ to 80.98$)$ & $0.0010 * * *$ \\
\hline $\begin{array}{l}\text { Normal } \\
\qquad(18.5-24.9)\end{array}$ & $10(24.39)$ & $14(58.33)$ & 1 & \\
\hline $\begin{array}{l}\text { Overweight/ Obese } \\
\qquad(25-\geq 30)\end{array}$ & $09(21.95)$ & $08(33.33)$ & $1.57(0.45$ to 5.50$)$ & 0.477 \\
\hline Total & 41 & 24 & & \\
\hline
\end{tabular}

Table 3. Association between Body Fat Percentage and Risk of Breast Cancer

\begin{tabular}{|c|c|c|c|c|}
\hline Variable (Body fat \%) & No. of Breast cancer cases (\%) & No. of Controls (\%) & OR (95\%confidence interval) & $P$ value \\
\hline $\begin{array}{l}\text { Underweight } \\
\qquad(10-25 \%)\end{array}$ & $25(60.98)$ & $08(33.33)$ & $1.33(0.27$ to 6.43$)$ & 0.0636 \\
\hline $\begin{array}{l}\text { Normal } \\
\qquad(26-31 \%)\end{array}$ & $07(17.07)$ & $03(12.50)$ & 1 & \\
\hline $\begin{array}{l}\text { Overweight/ Obese } \\
\qquad(31.1-40 \% \text { or more })\end{array}$ & $9(21.95)$ & $13(54.17)$ & $0.30(0.06$ to 1.46$)$ & 0.136 \\
\hline Total & 41 & 24 & & \\
\hline
\end{tabular}

menopausal cases [14]. Many studies have shown that there was a higher risk of breast cancer incidence among postmenopausal women with high BMI $[6-8,15]$. Based on ethnicity, a positive association between high BMI and increased breast cancer incidence has been observed in the Asia Pacific group than in the European-Australian or North-American group [16]. In India, few studies have shown a positive correlation between body mass index and breast cancer risk [17-20]. Using only BMI as an indicator for weight status overshadows other parameters such as body composition, adiposity, and adipose distribution [21]. Asian population have higher levels of total body fat, more abdominal fat and less-lean mass than other ethnic groups [22]. High central obesity (measured by waist to hip ratio) was reported to be the most important risk factor of $\mathrm{BCa}$, irrespective of menopausal and hormonal receptor status $[4,23]$. Postmenopausal women with a normal BMI but high body-fat levels [24] or high central obesity [8] were shown to have an elevated risk of breast cancer.

In the current work, we have categorized the sample population into underweight, normal and overweight/ obese, based upon BMI and body fat percentage. We observed that low BMI and low total fat in underweight cases, positively correlated with breast cancer risk. Although most of the studies have underlined a positive association between high BMI and increased risk of breast cancer, few reports have indicated that underweight pose a high risk for developing breast cancer. Underweight patients were reported to be at an increased risk of local recurrence among all types of breast cancer [9]. Women with low BMI have increased risk for premenopausal breast cancer compared to those with healthy BMI [25-28]. A hospital based case control study conducted in
Mumbai, India has reported a positive association between low BMI and increased breast cancer risk with high odds-ratio [4]. A multicentric study has shown association between low BMI and high risk of premenopausal breast cancer with increase in hazard ratios [29]. Underweight premenopausal women (BMI $<18.5$ ) with Luminal A and HER2 subtypes have shown risk for breast cancer [11]. A retrospective study in Chinese patients has suggested adverse outcomes in young underweight BMI $(<18.5)$ patients (under 40 years old) with lymph node metastasis [12]. Various mechanisms have been proposed underlying the association between underweight and breast cancer risk, out of which malnutrition is one of the important factors [30]. Malnutrition often leads to immune system dysfunction that may hamper tumor surveillance by immune cells and may also influence the efficacy of systemic antitumor therapies, thereby resulting into tumor dysregulation [31].

Our findings have important implications wherein a positive association was observed between low BMI, low total body fat and increased breast cancer risk. This underlines the significance of body fat in underweight population, which until now was not considered as a major risk factor. The present study has several limitations, the main one being the sample size. This pilot study warrants further studies on a larger sample size. Secondly, the patients need to be stratified based upon pre- and post-menopausal status, stage of cancer and hormone receptor status. This would strengthen our findings and further reiterate the significance of low BMI and low total body fat as important prognostic factors for management of breast cancer.

In conclusion, our study suggests that underweight status, based upon both low BMI and low total body fat, 
should be considered as a high-risk factor for breast cancer development and thus strategies should be developed accordingly for the prevention and management.

\section{Acknowledgements}

We thank Interactive Research School for Health Affairs (IRSHA), Bharati Vidyapeeth (Deemed to be) University and Bharati Vidyapeeth Hospital and Research Centre (BVHRC), Pune, India for their support in conducting this study.

\section{References}

1. Dutta M, Selvamani Y, Singh P, Prashad L. The double burden of malnutrition among adults in India: evidence from the National Family Health Survey-4 (2015-16). Epidemiology and Health. 2019 Dec 18;41:e2019050. https://doi.org/10.4178/epih.e2019050

2. Selvamani Y, Singh P. Socioeconomic patterns of underweight and its association with self-rated health, cognition and quality of life among older adults in India. Fürnsinn C. PLOS ONE. 201803 07;13(3):e0193979. https://doi.org/10.1371/ journal.pone.0193979

3. Bray F, Colombet M, Mery L, et al. (2017).(eds): Cancer Incidence in Five Continents, Volume XI. Lyon, France, IARC Sci. Publ.

4. Nagrani R, Mhatre S, Boffetta P, Rajaraman P, Badwe R, Gupta S, Romieu I, Parmar V, Dikshit R. Understanding rural-urban differences in risk factors for breast cancer in an Indian population. Cancer Causes \& Control. 2015 Nov 20;27(2):199-208. https://doi.org/10.1007/s10552015-0697-y

5. Rai RK, Fawzi WW, Bromage S, Barik A, Chowdhury A. Underweight among rural Indian adults: burden, and predictors of incidence and recovery. Public Health Nutrition. 2017 Nov 10;21(4):669-678. https://doi. org $/ 10.1017 / \mathrm{s} 1368980017003081$

6. Neuhouser ML, Aragaki AK, Prentice RL, Manson JE, Chlebowski R, Carty CL, Ochs-Balcom HM, Thomson CA, Caan BJ, Tinker LF, Urrutia RP, Knudtson J, Anderson GL. Overweight, Obesity, and Postmenopausal Invasive Breast Cancer Risk. JAMA Oncology. 201508 01;1(5):611. https:// doi.org/10.1001/jamaoncol.2015.1546

7. Gravena AAF, Romeiro Lopes T, Demitto MDO, Borghesan DHP, Dell' Agnolo CM, Brischiliari SCR, Carvalho MDDB, Pelloso SM. The Obesity and the Risk of Breast Cancer among Pre and Postmenopausal Women. Asian Pacific Journal of Cancer Prevention. 2018 09;19(9). https://doi. org/10.22034/APJCP.2018.19.9.2429

8. Park YM, White AJ, Nichols HB, O’Brien KM, Weinberg $\mathrm{CR}$, Sandler DP. The association between metabolic health, obesity phenotype and the risk of breast cancer. International Journal of Cancer. 201703 28;140(12):2657-2666. https:// doi.org/10.1002/ijc.30684

9. Moon H, Han W, Noh D. Underweight and Breast Cancer Recurrence and Death: A Report From the Korean Breast Cancer Society. Journal of Clinical Oncology. 2009 Dec 10;27(35):5899-5905. https://doi.org/10.1200/ jco.2009.22.4436

10. Tan F X, Gummadi S, et al. Impact of Body Mass Index on Prognosis for Breast Cancer Patients. jwhg. 201904 30;6(3). https://doi.org/10.17303/jwhg.2017.4.202

11. Jeong SH, An Y, Ahn C, Park B, Lee MH, Noh D, Park SK. Body mass index and risk of breast cancer molecular subtypes in Korean women: a case-control study. Breast Cancer Research and Treatment. 2019 Oct 18;179(2):459470. https://doi.org/10.1007/s10549-019-05451-1

12. Chen B, Lai J, Guo L, Dai D, Chen R, Wei G, Liao N. Adverse effects of being underweight on young female breast cancer patients with lymph node metastases. Journal of Cancer. 2020;11(7):1976-1984. https://doi.org/10.7150/ jca. 38567

13. Suzuki R, Saji S, Toi M. Impact of body mass index on breast cancer in accordance with the life-stage of women. Frontiers in Oncology. 2012;2. https://doi.org/10.3389/ fonc. 2012.00123

14. Elkum N, Al-Tweigeri T, Ajarim D, Al-Zahrani A, Amer SMB, Aboussekhra A. Obesity is a significant risk factor for breast cancer in Arab women. BMC Cancer. 2014 Oct 29;14(1). https://doi.org/10.1186/1471-2407-14-788

15. Benn M, Tybjærg-Hansen A, Smith GD, Nordestgaard BG. High body mass index and cancer risk-a Mendelian randomisation study. European Journal of Epidemiology. 201604 09;31(9):879-892. https://doi.org/10.1007/s10654016-0147-5

16. Wang J, Yang D, Chen Z, Gou B. Associations of body mass index with cancer incidence among populations, genders, and menopausal status: A systematic review and metaanalysis. Cancer Epidemiology. 2016 06;42:1-8. https://doi. org/10.1016/j.canep.2016.02.010

17. Kapil U, Deo S, Singh P, Shukla N, Dwivedi S. Association of overweight and obesity with breast cancer in India. Indian Journal of Community Medicine. 2011;36(4):259. https:// doi.org/10.4103/0970-0218.91326

18. Inamdar P, Mehta G. Correlation Between Obesity and High Density Lipoprotein Cholesterol (HDL-C) in Breast Cancer Patients of Southern Rajasthan. Indian Journal of Surgical Oncology. 2011 05 06;2(2):118-121. https://doi.org/10.1007/ s13193-011-0070-x

19. Naushad SM, Hussain T, Al-Attas OS, Prayaga A, Digumarti RR, Gottumukkala SR, Kutala VK. Molecular insights into the association of obesity with breast cancer risk: relevance to xenobiotic metabolism and $\mathrm{CpG}$ island methylation of tumor suppressor genes. Molecular and Cellular Biochemistry. 201403 28;392(1-2):273-280. https://doi. org/10.1007/s11010-014-2037-z

20. Antony MP, Surakutty B, Vasu TA, Chisthi, M (2018). Risk factors for breast cancer among Indian women: A casecontrol study. Niger. J. Clin. Pract., 21-4.

21. Bandera EV, Chandran U, Zirpoli G, Gong Z, McCann SE, Hong C, Ciupak G, Pawlish K, Ambrosone CB. Body fatness and breast cancer risk in women of African ancestry. BMC Cancer. 2013 Oct 14;13(1). https://doi.org/10.1186/14712407-13-475

22. Misra A. Ethnic-Specific Criteria for Classification of Body Mass Index: A Perspective for Asian Indians and American Diabetes Association Position Statement. Diabetes Technology \& Therapeutics. 2015 09;17(9):667-671. https:// doi.org/10.1089/dia.2015.0007

23. Barberio AM, Alareeki A, Viner B, Pader J, Vena JE, Arora P, Friedenreich CM, Brenner DR. Central body fatness is a stronger predictor of cancer risk than overall body size. Nature Communications. 201901 22;10(1). https://doi. org/10.1038/s41467-018-08159-w

24. Iyengar NM, Arthur R, Manson JE, Chlebowski RT, Kroenke CH, Peterson L, Cheng TD, Feliciano EC, Lane D, Luo J, Nassir R, Pan K, Wassertheil-Smoller S, Kamensky V, Rohan TE, Dannenberg AJ. Association of Body Fat and Risk of Breast Cancer in Postmenopausal Women With Normal Body Mass Index. JAMA Oncology. 201902 
01;5(2):155. https://doi.org/10.1001/jamaoncol.2018.5327

25. Wada K, Nagata C, Tamakoshi A, Matsuo K, Oze I, Wakai K, Tsuji I, Sugawara Y, Mizoue T, Tanaka K, Iwasaki M, Inoue $\mathrm{M}$, Tsugane $\mathrm{S}$, Sasazuki S. Body mass index and breast cancer risk in Japan: a pooled analysis of eight population-based cohort studies. Annals of Oncology. 2014 02;25(2):519-524. https://doi.org/10.1093/annonc/mdt542

26. Mamun AA, Finlay JE. Shifting of undernutrition to overnutrition and its determinants among women of reproductive ages in the 36 low to medium income countries. Obesity Research \& Clinical Practice. 2015 01;9(1):75-86. https://doi.org/10.1016/j.orcp.2014.03.001

27. Engmann NJ, Golmakani MK, Miglioretti DL, Sprague BL, Kerlikowske K, . Population-Attributable Risk Proportion of Clinical Risk Factors for Breast Cancer. JAMA Oncology. 201709 01;3(9):1228. https://doi.org/10.1001/ jamaoncol.2016.6326

28. Kim JH, Yoon KH, Hur H, Park S, Kim JY, Park HS, Kim SI, Cho YU, Park B. Prevalence of breast cancer-related risk factors in underweight premenopausal women: the Korea National Health and Nutrition Examination Survey IV-VI. Breast Cancer Research and Treatment. 2018 Dec 17;174(2):515-524. https://doi.org/10.1007/s10549-01805091-x

29. , Schoemaker MJ, Nichols HB, Wright LB, Brook MN, Jones ME, O’Brien KM, Adami H, Baglietto L, Bernstein L, Bertrand KA, Boutron-Ruault M, Braaten T, Chen Y, Connor AE, Dorronsoro M, Dossus L, Eliassen AH, Giles GG, Hankinson SE, Kaaks R, Key TJ, Kirsh VA, Kitahara CM, Koh W, Larsson SC, Linet MS, Ma H, Masala G, Merritt MA, Milne RL, Overvad K, Ozasa K, Palmer JR, Peeters PH, Riboli E, Rohan TE, Sadakane A, Sund M, Tamimi RM, Trichopoulou A, Ursin G, Vatten L, Visvanathan K, Weiderpass E, Willett WC, Wolk A, Yuan J, ZeleniuchJacquotte A, Sandler DP, Swerdlow AJ. Association of Body Mass Index and Age With Subsequent Breast Cancer Risk in Premenopausal Women. JAMA Oncology. 2018 Nov 08;4(11):e181771. https://doi.org/10.1001/ jamaoncol.2018.1771

30. Sengupta A, Angeli F, Syamala TS, Dagnelie PC, Schayck CV. Overweight and obesity prevalence among Indian women by place of residence and socio-economic status: Contrasting patterns from 'underweight states' and 'overweight states' of India. Social Science \& Medicine. 2015 08;138:161-169. https://doi.org/10.1016/j.socscimed.2015.06.004

31. Bourke CD, Berkley JA, Prendergast AJ. Immune Dysfunction as a Cause and Consequence of Malnutrition. Trends in Immunology. 2016 06;37(6):386-398. https://doi. org/10.1016/j.it.2016.04.003

This work is licensed under a Creative Commons AttributionNon Commercial 4.0 International License. 